Regmi, Mahesh C. 1976, Landownership in Nepal, Berkeley: University of California Press.

Rosser, Colin 1966, "Social Mobility in the Newar Caste System" in C. Von Fürer-Haimendorf (ed.) Caste and Kin in Nepal, India and Cyelon, Bombey: Asia Publishing House.

Srinivas, M.N. 1966, Social Change in Modern India, Berkeley: University of California Press

Sharma, Balchandra 1978 (2033 v.s.), Nepalko Aitihasik Ruparekha (An Outline of the History of Nepal), Baranasi: Krishna Kumari Devi.

Sharma, Prayag Raj 2004, "Introduction" in András Höfer, 2004, The Caste Hierarchy and the State in Nepal: A Study of the Mulki Ain of 1854, Kathmandu: Himal Books.

Sharma, Prayag Raj 1978, "Nepal: Hindu-Tribal Interface" in Contributions to Nepalese Studies, Vol. 16, No. 1, pp. 1-4.

\section{ADAPTATION AND IDENTITY OF YOLMO}

Binod Pokharel

\section{An Overview}

This article focuses on adaptation and identity of Yolmo people living in the western part of the Sindhupalchok district. The Yolmo are traditionally herders and traders but later they diversified their economy and are now relying on tourism, wage labour and work aboard for income. It is believed that they arrived in the Melamchi area from Tibet from the $18^{\text {th }}$ century onwards. This article basically concerns on how Yolmo change their adaptive strategy for their survival and how did they become successful in keep their identity even though they have a small population. The economic adaptation in mountain region is very difficult due to marginal land and low productivity. Therefore they diversified their economy in multiple sectors to cope with the environment. Bishop states that "diversification involves exploiting one or more zones and managing several economic activities simultaneously" (1998:22). Adaptation is an active process because neither the organism nor its environment remains constant. New problems and new solutions to the old problem arise. Each community has its own survival pattern. Such pattern is partly determined by environmental conditions and partly by socio-cultural system (Hardesty 1977). 


\section{Understanding the Concept of Adaptation}

Anthropology is the study of physical and behavioural aspects of human beings. Cultural ecology is a sub-branch of anthropology which directs our attention to the problem of human survival within specific environment (Fricke 1993). Adaptation is the central theme in anthropology whereby beneficiaries organism/environment relationship is established (Hardesty 1977). Most of the cultural ecological studies focus on environmental adaptation, adaptive process and survival strategies of particular groups. Adaptation also denotes the coping mechanisms utilized by organisms during their lives (Bennett 1996) in the given environment. Each group or individual has its own strategy for survival. Adaptation can be held in group and individual level. In this regard Bennett (1976) mentioned that a certain type of adaptative strategy is followed by individuals can be adaptative for them. However, adaptation for individuals may or may not be adaptive or maladaptive for group and environment. It is a living mechanism of the human being in a particular environment. Julian Steward who pioneered the study of cultural ecology suggested that the explanation for cultural variation could be found in the adaptation of societies to their particular environment (1955).

In the beginning adaptation was considered as coping mechanism with local environment. The earlier studies had tendencies to stress equilibrium aspect of cultural adaptation to environment (Fricke 1993). Now many anthropologists give emphasis on political and institutional aspect to study the adaptive process of the particular community (see Graner 1997; Metz 1989). In the past, many communities depended on animal husbandry and agriculture and they exploited the local environment for their survival. However, many traditional communities have now been exposed to outside world and monetized economy due to the national and international intervention and development. Adaptability is the capacity to expand niches or to find new niches. Adaptation and maladaptative behaviour in humans is based on the capacity for self-objectification and normative orientation (Hallowell, 1960 cited by Bennett 1996:31).

Hardesty defines that "cultural behaviour is patterned, shared and traditional and the most distinctive features of the human species" (1977:24). He has categorized cultural behaviour in three groups (See Table 1).

\section{Table-1 Facets of Culture}

\begin{tabular}{ll}
\hline Facets & Cultural Characteristics \\
\hline Technology & $\begin{array}{l}\text { All equipments made by human beings from digging } \\
\text { stick to nuclear power plant }\end{array}$ \\
\hline Organization & $\begin{array}{l}\text { Kinship, social rank, stratification, voluntary } \\
\text { associations and politics among other things }\end{array}$ \\
\hline Ideology & $\begin{array}{l}\text { Value, norms, knowledge, themes, religious belief, } \\
\text { sentiments, etc. }\end{array}$ \\
\hline
\end{tabular}

Source: Kaplan and Manners, 1972 cited by Donald Hardesty 1977:24.

Adaptive process is an achievement oriented for human species. Bennett views that adaptive behaviour refers to any form of behaviour that adjusts means to ends, accomplishes objectives, achieves satisfaction, exercise choice, or avoids or refuses action or involvement in order to adapt or adjust (1976).

In the transition of adaptation certain images of humanity are replaced by others. Bennett writes that "the transition is marked by the expansion of ecological impact resulting from the accumulation of substances and objects for social purposes unrelated to the biological survival" (1976:6). 


\section{Understanding Adaptation in the context of Nepal}

The literature on adaptation in Nepal in relation to subsistence strategy of small population mostly focuses on interrelationship between local ecology and population. In constrast, Stevens (1993) has done a study on subsistence and environmental change in Khumbu of Solukhumbu applying regional approach to understand the adaptive strategy of the Sherpa. Most of the past studies are centered to micro level cultural ecosystem in Nepal. However, Stevens offered both micro and macro level analysis of Sherpa cultural ecology and highlights the political economy of the Sherpa land. He has dealt with environmental change and land use from the perspective of individual and managers. He uses the term manager in a broader sense which includes all people and institutions. Institutions refer to development agencies, and local, regional, national and international government and institutions. $\mathrm{He}$ mentioned that with the Chinese occupation over Tibet the trade on Sherpa area decline and they were attracted by tourism. Sherpas have developed multiple adaptive strategies for their subsistence. In this regards Stevens states: "the people of the Himalaya, like those of other highland regions, have developed a number of different adaptive strategy and practices for subsisting in distinctive conditions of mountain ecosystems" (1993:58).

Stevens states that there are several interventions (tourism development, establishment of National Park, etc) in Sherpas' land but they have been successful in preserving their own culture partly due to their relative isolation and distance from low land areas and Hindu culture. He concludes that they accommodated the new inventions in their culture. Unlike Khumbu Sherpas, however, the Yolmo have only recently become involved in tourism sector, and this is to a limited degree. Bishop (1998) mentioned that Yolmo depend on livestock production and out-migration for income to a high degree.
Chhetri (1987) analyses the adaptation process of Thakali in uraban center to understand migration, adaptation and socio-cultural change of the Thakalis of Pokhara. He observes that migrant Thakalis are preserving some aspects of their indigenous culture with some adaptational changes. He notes that Thakalis tend to show an enclosed and isolated character in terms of culture and religion. But they tend to be open and showing a desire to adapt to socio-economic life in the uran center (1987:63). Similarly, he (1990) examines adaptation of Tibetan refugees in Nepal in the context of persistence and change in socio-cultural, economic, religious and demographic aspects.

Naomi Bishop (1998) describes the tradition, adaptation and change among the Yolmo people of Melamchi valley. She also examines the socio-economic transformation of Yolmo from 1971 to 1993. In this regard the author mentions: "between 1971 and 1993 the Melamchi economy continued to shift away from agro-pastoralism and a subsistence economy and toward a dependence on circular migration and cash" (1998:142).

According to Bishop transhumant practice has gradually decreased since mid 1970s and people began seasonal migration to India. She argues that establishment of the National Park in the Yolmo land and restriction on traditional subsistence activities that supported animal husbandry is responsible for the decline in transhumant activities in Melamchigaun.

Fricke (1993) with a demographic approach focuses on the adaptive process of Tamangs of Timling. His concern is to explain how birth, marriage and death determine the adaptive mechanism of the households. He contends that the number of children in a households influence the diversification of the household economy. In this regards Fricke writes: 
The household labour force is largely determined by the facts of birth and death. Some household will have many sons, others none at all. Further, the extent of property that the household begins it life with will be partially determined by the size of sibling groups within which land and other capital must be divided (1993:132).

Children are considered as an asset due to labour potentiality when they reach 16 and 17 years. He observes the direct benefit of having more children among the Tamang of Timling. He notes that "a large household is not simply secure in its diversified economy. It is also in a strong position to expand its holdings" (1993:185).

Augusta Molnar (1981) carried out a study on Kham Magar applying ecological model to describe a subsistence economy. She focused on four Kham Magar communities (Thabang, Lubang, Taka and Maikot) of western Nepal. All of these communities mainly depend on herding and agriculture. However, there are differences in economic strategies among them. Culturally, they share common value system and marriage practices. They speak the same dialect known as Kham language (a dialect belonging to Tibeto-Burman language family). However, the available natural resources and harvesting strategies make differences. Originally, all of them were involved in herding. According to the author Taka and Maikot have a greater access to northern pasture land. Lubang and Thabang have no easy access to northern pasture land due to change in pasture landrights and charges. The author has analyzed the main constraints for adaptation of Kham Magar: access to pasture land, trade pattern, seasonal labour availability, cultural attitude towards animal husbandry and education. These constraints have determined the adaptive process of the four communities.

Desjarlais (2003) has carried out a study on Yolmo people. He applied person centered approach to cultural phenomena. The aim of this research to show how the dominant sensory orientations of the modern west are historically distinct and it tends to focus on culturally pervasive themes and dynamics. The goal of the author is to understand how sensory modalities and dispositions play themselves out in individual lives, how members of a single society live out different sensory biographies. Although Desjarlais' focus is not much on adaptation his work is important in that he analyses the Yolmo perception towards the contemporary society and world.

In the present study I look at Yolmo's adaptation to environmental and socio-cultural condition as well as changes resulting from internal and external forces. My attempt is to understand how they shift from herding and focus more on seasonal labour migration and hotel business. The Yolmo are exposed to the outer world in several ways but how they become successful to preserve their own identity is also an issue of concern.

\section{Helambu: Home of the Yolmo People}

Helambu is the traditional homeland of the Yolmo people. The upper reaches of the Melamchi Valley is occupied by Yolmo people. The study area lies within the Buffer Zone of Langtang National Park. In addition, the Tupu Cave is close to Sermathang where the famous Guru Rimpoche meditated. Yolmo are Buddhist and economically they practice a combination of mixed agriculture comprising of livestock herding and business ventures such as hotels, restaurants and trading as far a field as India. Now they are gradually shifting from their traditional occupation into national and international wage labour. The total population of Yolmo in Melamchi Valley is 4577 (CBS 2002). The main settlements are Melamchi Ghyang, Tarke Ghyang, Nakote, Kangyul, Sermathang, Norbugoun, Timbu and Kutumsang. Among them Melamchi Ghyang, Tarke Ghyang and Sermathang are densely populated areas. These areas make a common name called Helambu. A few Yolmo houses are found in the Yangri and Larke valley to the 
north-east of Sermathang. There are also Yolmo people residing other parts of the country such as Gorkha district (Bishop 1998:14).

The present study is confined in Sermathang which lies in the upper reach of the Kiul Village Development Committee (VDC) of Sindhupalchok district. It is a part of Melamchi valley. It takes one day's walk from Melamchipul Bazar to reach Sermathang. The study village is located in moderately sloped terrain. It is situated at an elevation of about 2700 meter high from the sea level. There are sixty Yolmo households with a total population 350 populations. Each entrance of Sermathang has prayer flags and mane (stupas containing prayer wheels). Bishop records a significant population growth in such a settlement after the1920s. The population growth is likely related to the change in livelihood systems from predominantly herders to mixed agriculture after the introduction of wheat, barley and potatoes. By the 1970s the last areas of cultivation were developed in most of the area (Bishop 1998:20). Villages such as Melamchi Ghyang, Sermathang, etc., were probably originally summer residences for herds and only later developed into permanent settlements.

The Yolmo are the numerically largest ethnic group of people in the upper part of the Melamchi valley. The middle part of the valley has predominantly Tamang population. The lower part of the valley is populated by "high castes" and mixed group of people. The Yolmo have economic relation with caste groups of low land and they have both economic and marriage ties with Tamang people. They can be clearly distinguished from their neighbouring nonYolmo such as Tamang, Magar and caste groups in terms of language, social structure and shared history. Desjarlais (2003: 8) notes that Tamang families are poorer than Yolmo and they often serve as labourers for Yolmo. However, there are some sorts of commonalities between Tamang and Yolmo due to their same religious affiliation.

There is more attraction of local people towards the Yolmo culture. The Tamangs living in the Yolmo region, in fact, claim that they themselves are Yolmo. The Tamang and Magars who live close to Yolmo settlements have adapted many cultural traits of Yolmo people. Many of them have forgotten their own language and speak the Yolmo language. Some of them have adapted Yolmo surnames. According to them the area between Indrawati and Melamchi rivers is called Helambu region and the people who live in this area are generally known as Yolmo. The reason for adaptation of Yolmo culture by other groups is economic since most of the tourist coming in Yolmo region would like to spend in the hotel run by Yolmo. Like Sherpa of the Yolmo people are renowned for strength, courage, endurance and deep faith on Buddhism and also attract other local group to adapt the Yolmo culture.

\section{Historical Background: People in Helambu}

The term Yolmo is derived from the Tibetan language and means 'place screened by snow mountain or glaciers' (Bishop 1998:12). According to earlier anthropological studies, it is likely that the Yolmo were settled here by $18^{\text {th }}$ century and originated from Kyirung region of Tibet, approximately a 3-4 days' trek from Helambu (Clark 1980; Bishop 1998:13-17). A local informant told me that a group of Tamang had invited the Yolmo to the Melamchi valley. According to the oral history of Yolmo, when the Tamang fled from Tibet and settled down in the Helambu region they did not have any Lama (ritual specialist). When a Tamang died, there was no Lama in the Tamang Communities for ritual purification. Without a Lama, the dead could not be buried properly according to Buddhist and Tibetan religious traditions. So, some of the Tamang visited Tibet and requested Yolmo Lama to settle down in 
Helambu. This oral history contradicts the historical evidence since genealogical data suggests that the arrival of Yolmo Sherpa was not more than seven generation ago and the Tamang's arrival in valley are hundreds of years ago (see figure-1).

\section{Figure 1 : Ganealogical Chart - Yolmo-Mingar Lama}

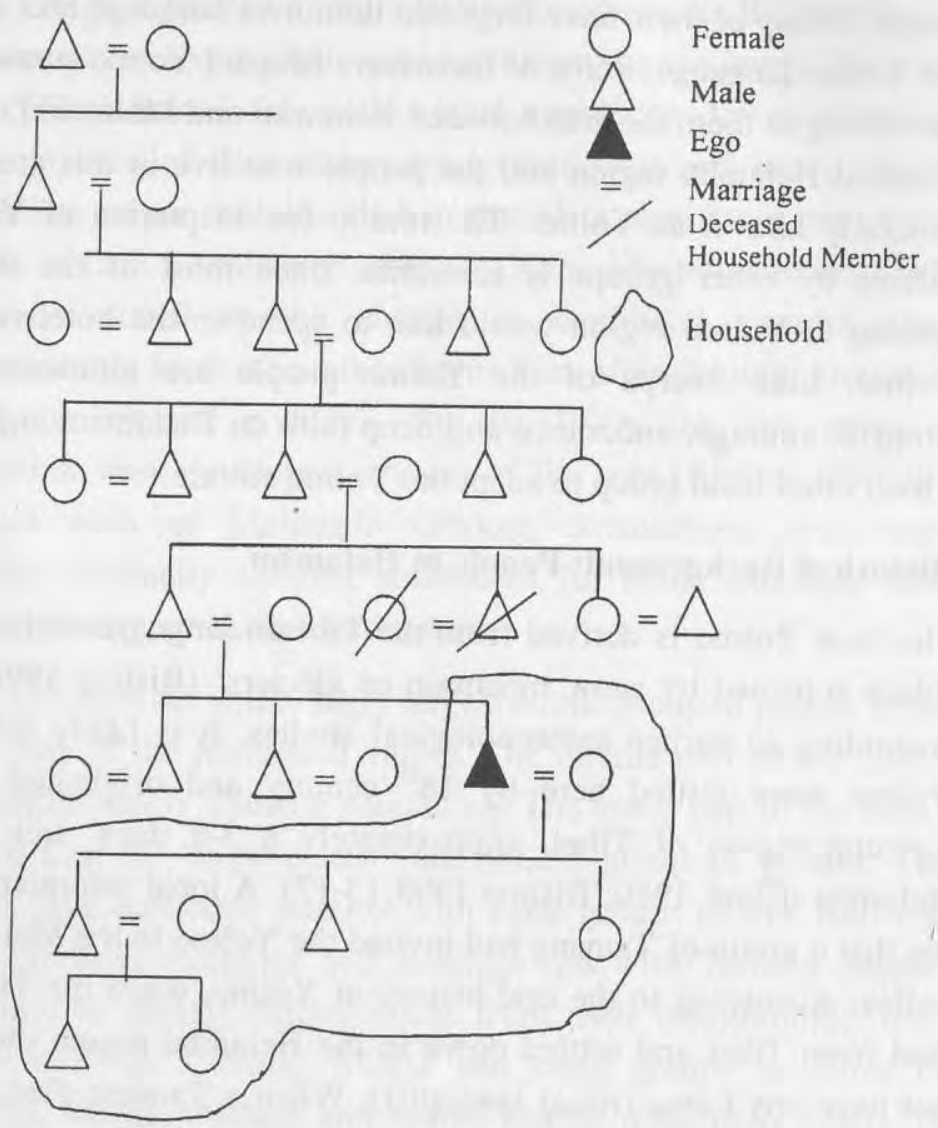

Figure 1-1 shows that Yolmo lives in joint families and often three generaions can be found living under the same roof. As indicated in fugure 1-1 decent is through the male but practical cirmumbstances such as location, socio-economic status and personal reasons are taken into account to determine which son will be responsihble for taking care of his parents in old age
The story illustrates rather the ritual dependence of the Tamang on the Yolmo people, the later having ties with religious institutions in Tibet. The settlement pattern of Yolmo indicates that all Yolmo did not come at the same historical epoch. They come and settled down from different places of Tibet in different time. Some of them did not come directly to Helambu. In this regards one of my informants said that his forefather first settled in Langtang village of Rasuwa district and later migrated into Helambu. Similarly, Yolmo language is similar to Tibetan language than eastern Sherpa from Solukhumbu, "which may indicate that Yolmo was settled more recently" (Bishop 1998: 15). Yolmo is the language of daily communication for Yolmo people.

\section{Natural Resources and Utilization}

Yolmo region is rich in natural resources. Sermathang comprises forest, grass land, shrub land, and agricultural land. According to LNP (Langtang National Park, 2001) less than two percent of the total land in Helambu region is under agriculture. The forest area is large occupying approximately 30 percent of the total land. A large proportion of the land area lies under the rocky and waste lands. There are two main river systems, i.e., Melamchi and Indrawati. The complex topography and geology of the park area are reflected in the wide spectrum of bio-diversity. The Yolmo region includes a wide variety of vegetation including endemic and localized species such as rhododendron, oak and coniferous forest. The recorded mammalian fauna of the park is 46 species including snow leopard, clouded leopard, musk deer, red panda and Assamese monkeys.

Yolmo people had their own pasture land and forest land. The right of occupancy and use of the land for individuals and villages were determined by ghyang (monastery) and chief Lama of ghyang. The guthi land (trust land) of the Yolmo region was designated to ghyang. Bishop (1998: 54) notes that permission for land utilisation 
was generally granted, and after a small payment to the ghyang, the land was theirs. In 1980 land cadastral survey was held in Melamchi Valley. The survey registered the village land with the government in the villagers own name (Bishop 1998:55). Still there are large areas under guthi land. According to local tradition people who live on guthi land are responsible for managing the ghyang. Some of the ghyangs have paddy fields in low land of the Melamchi valley which are cultivated by non-Yolmo people on fixed rent basis.

After the establishment of National Park (1976) these resources came under the jurisdiction of the government. People within the park area are allowed to collect fuel wood from dead trees for cooking and heating purposes. However, the demand of firewood has increased due to arrival of tourist and establishment of hotels, To cope with the increasing firewood demand the people have planted trees on the edge of the agricultural land and LNP introduced solar energy to reduce the rate of firewood consumption. Timber is used basically to repair/construct house, hotel, school, and monastery. One should pay royalty for timber to the national park. If they need more timber they borrow or buy from the guthi jungle holders. Due to this intervention the Yolmo cultivated several habits in the field of forest consumption. Now people installed improve stove which consumes little firewood than traditional one. Some of the hotel owners have recently introduced LP gas and kerosene stove in the study areas. There are the records of change in forest consumption pattern in other parts of the country due to intervention of National Parks. In this regards Stevens (1993) mentioned that the Sherpa experienced the greatest change in their firewood collection due to Sagarmatha National Park. The traditional institution 'nawa' roles replaced by the park and several restrictions were made for grazing and collecting firewood. However there was no concept of nawa in Yolmo region.
Traditionally forests were under the jurisdiction of guthi. People used to harvest the forest resources by paying the tax to guthi. Some of the houses were constructed within the guthi land and they also pay the taxes to guthi in annual basis.

A Forest User Group is formed in Sermathang comprising four wards of Kiul VDC. Forest user group represents each household of the village, hamlet or settlement. The forest user groups are mainly concerned on conservation of natural resources, community development and utilization of forest products. Theoretically, community forestry scheme in the Buffer Zone is explicitly targeting the people of buffer zone. The park has invested in afforestation on private and public land with the substantial local support. People can make own decision on conservation, management and utilization of the forest products. However, there is the requirement of approval from the chief warden of the National Park for each decision made by the Forest User Group. As like the Sherpa of Khumbu the Yolmo also accommodate the Forest User Group concept within their culture.

\section{Cultural Landscape}

The cultural landscape of Helambu region is rich in terms of religious structure and monuments. Most large Yolmo Sherpa village can be considered temple villages (Bishop 1998) since they contain ghyangs and have a religious routine and community obligation towards these institutions. Many of the larger gomba complexes, such as the one at Melamchi ghyang are artistic and architectural wonders with frescos, thankas and ancient books of historical value. The maintenance and restoration of these structures have been carried out by the community through the contribution of labour and cash by locals. 


\section{Ghyang}

Ghyang is socio-religious institution of Yolmo community. However, other group can also go ghyang for prayer and can contribute. Gomba and ghyang are synonymously used in the study area. There are images of gods and religious paintings in the ghyangs as well as religious texts written in Tibetan script. In all Yolmo villages there is a roadside stone wall called a mane is built as memorials to dead persons. Each household is linked to gomba. Most of the rituals including funeral rites and festivals are organized in Ghang. Most of the ghang has guthi land and forest land. The income coming from the guthi land is used for daily worship of ghang and to cover the cost of chief Lama. The income of the guthi land does hardly cover the actual expenses of the ghang therefore the households living near the ghang raise the funds on rotational basis. In the past they used to provide some portion of their land and animal products (crops and ghee) to make a ghang functional. Bishop mentions that the contribution for ghang was based on the sizes of landholding (1998). Now the situation has changed. Many Yolmo are away from the village. They earn cash through business and wage. Each member of ghang sends money to ghang on his or her turn. As informed by chief Lama of Kesari ghyang, Sermathang a member sends at least 15,000 to 20,000 thousand rupees in his turn. Respective households living in Sermathang cover all expenses and needs of that ghang.

\section{Belief System}

They have two major belief systems. In this regards Sparks and Pokharel note:

The Yolmo Sherpa appear to have two parallel belief systems that are at times complementary and at times competitive. This is best illustrated by the roles of two ritual specialists: the Lama and the Bombo. The former resides in monasteries and represents the Tibetan monastic Buddhist traditionavoidance of violence, dependence on the lay population for food and support and participation in large communal and mortuary rituals. The latter are local practitioners of the spirit world and how that affects the day to day living of the people (2003: 45).

Lama does not plough field. According to Buddhism one should not give torture to any living things. Non-Lamas can plough the field. Lama as a religious teacher does not till the field and perform other heavy physical work. But Bombos can perform such tasks. According to Yolmo tradition the main responsibility of the Lama is to conduct cremation and funeral rites (Desjarlais 2003: 11).

Lhosar is the biggest festivals for Yolmo and celebrated as the New Year festival. Nara is a long festival that falls in the time of Hindu Dasain. The other major festivals of the Yolmo region are Dhukpa, Chhuju, Hyulka Chheju, Torpe. The Yolmo never plough and plant seeds during days proceeding and following the full moon and new. moon. On these days there are religious rites held in the gomba.

They celebrate ubhauli and udhauli puja, which involves the worship of the earth deity responsible for providing food. Ubhauli is celebrated before monsoon or beginning of agriculture cycle. The people pray for sufficient rainfall and a good harvest. In the past this festivals was considered as making the movement from low altitudes to higher summer pasture. Udhauli symbolizes the beginning of winter when the herds gradually come down to lower altitudes and when harvesting is almost complete. In this ceremony they thank to earth deity for a good harvest and wish for a good harvest next year.

\section{Housing}

The cultural landscape as reflected in house types and architecture of the building are almost similar in most village settlements in 
Sermathang. Timber, mud and stone are the main construction materials for the construction of Yolmo houses. They used slate for the roofing of the house. Now newly constructed houses are roofed by Corrugated Galvanized Iron sheet. The traditional roofing is costly which requires a tremendous investment in wood and labour, especially since "it must be replaced every five years" (Bishop 1998:49). Restriction of free collection of timber from forest and durability of sheet tin attract them to replace the traditional roofing style. The houses are two storied. Cowshed is placed within the compound of the main house. The compound wall of the house is fenced with dry stone wall. A hotel owner Yolmo would generally construct two houses one for hotel use and the other for personal uses. In some cases rooms are added to the existing house, joining it rectangularity. Houses are not simply physical structures. Houses express symbolically, through architectural design, decoration and lay out, their purposes and the pertinent characteristics of their habitants (Howell 2003). The houses of Yolmo are peculiar one. The doors and windows are carved beautifully. The kitchen is well decorated and spacious. Bishop nicely described the kitchen arrangement of Yolmo Sherpa. She says:

People sit around the fire, for sociability and warmth, always eating something. Those of higher status sit next to the host, in order of descending status, so newcomers arrive, there is a shuffling of location as people adjust The female householder sits on the left side of the fire, she is surrounded by working equipment and food stores and can serve the entire house from her vantage point(1998:50). .

The settlement and village pathways are stones paved and are quite orderly and clean. Courtyard is also paved with stone and is regularly swept. The Yolmo puts a prayer flag in the courtyard of the house. This flag clearly distinguishes the Yolmo houses from others.

\section{Social Organization}

Yolmo society is patrilineal society and organized into clans. As reported by the informants, there are seven clan groups of Yolmo in the Helambu region such as Dong Biruchan, Jhyapa, Syangba, Chujhyang, Waiba, Salma and Nirgma. Cross-cousin marriages are the ideal for producing and cementing alliances between clans (Sparkes and Pokharel 2004). However, most of them write Lama as a surname instead of their clan name. However, only Syangba is Lama by lineage. Bishop notes that the Yolmo called themselves "Yolmo people" or Sherpa from Yolmo. Since government personnel refer as Lama People, they often add this term as a surname in citizenship papers and official documents (1998:13) Yolmo used to call themselves as Sherpa or Helambu Sherpa in the late 1960s (Desjarlais 2003:12). Previously, they call themselves Lama People to distinguish themselves ethnically from Tamang clans (Ibid: 12). In the past one could be Lama if he was able to read holy text. In this regards Sparks and Pokharel (2003) comment that this adaptation or change is probably due to the imposition of the Nepal ethno-caste classification where one's last name indicates one's place in the hierarchy. In addition, the Lamas had high status within Yolmo society as learned people. In this community one can be Lama (non-Buddhist person also) if he can read Tibetan and Buddhist texts. Desjarlais notes that after 1990s they reconstruct the collective identities and now they identify themselves as Yolmo people (2003:12)

The Yolmo of the study area can be described as having consanguineous kinship rather than affinal kinship that is relations by blood dominate rather than through marriage or in-marriage into clans (Sparkes and Pokharel 2004). They mostly employ the descriptive kinship terminology. They use different kinship terms for different relative by kinship terminology. However, few terminologies are explanatory in nature such as they use mheme for 
father's father and mother's father and mum for father's mother and mother's mother. They use the same terminology for elder brothers and wife's elder brothers (jyo-jyo). Most of them live in joint family (see genealogical figure-1).

Both religious and social power is enjoyed by the chief Lama of the gomba. After 1970s several local elections were held in the Yolmo region but there is no evidence of confrontation between Lama and chairperson of the VDCs. The community acknowledges the power, roles and responsibilities of Lama.

The Yolmo are basically egalitarian. There is no explicit social hierarchy and the concept of purity and pollution, which marks caste distinctions, is lacking. Desjarlais (2003) notes about the social hierarchies among the Yolmo people. He writes:

Lamas, who usually inherit that role patrilineally, call for respectful deference more than lay person do; wealthy families are to pay respect to the elderly, and husbands have higher status than wives.

\section{Marriage Practices}

Bishop reports that there was considerable intermarriage between the Yolmo clans and indigenous Tamang (1998:98). Both groups are patrilineal and patrilocal and organized into clans. The most common form of marriage is capture marriage where the bride is captured by friends of the groom and forced to marry the groom at his residence. Most marriages are arranged or at least have the consent of elders and often the knowledge of the bride. However, there are many examples of force and coercion. Bishop reports three stages (1998: 98-99):

1. Seeking permission of the bride's parents-nama langdwang-and presents are given and the wedding planned.
2. The capture in the early morning (with feigned planned) and meal and ceremony at the house of the groom.

3. Presentation of the bribe price (toljung) with both families present- a formal recognition of the marriage.

However, the incidence of capture marriage and cross cousin marriage has been decreased in the study area. Most of the young generations of Yolmo live outside of the village for schooling, wage labour, business and foreign labour. As reported most of the marriage is now held in their work place and later they come into village for social acceptance and ritualistic formality.

\section{Economy of Yolmo}

Traditionally Yolmo are herders and traders. They almost gave up the herding business and continue the trade in other forms. They used to barter animal products and potato with cereal crops with low land people. Now the economy of the Yolmo is highly diversified. They are found engaged in multiple occupations so that all sons no longer reside in the village since they go to business in Kathmandu or migrate for wage labour. All brothers contribute for main house and become independent from parental property. For example an informant of Sermathang has two sons one lives in the USA with his wife. The grandson and grand daughter of respondent are studying in Kathmandu. The other son and one daughter of the respondent have not yet married and run the hotel in the village. The brothers of the respondent do not live in the village. One of them lives in Baudhha, Kathmandu and another in India. Having a number of children helps to expand the economy of the households in mountain or high altitude region. The finding of Fricke (1993) seems to agree with the case of Yolmo. If some one has more siblings they can extend their economy within the village or beyond the village. According to the Fricke those who have more children 
they can exchange their labour with their relative and domestic economy can boost up. He argued that the population growth at family level created the economic opportunity for the family is question.

One of the major source of cash earning is business in Yolmo region i.e. tourism and hotel. The family members who stay at main house handle hotel, other business and agriculture. The other family members either are in national and international labour or carpet weaving in Kathmandu. Some of them have settled permanently in Kathmandu and are involved in trading and carpet weaving. They used to be involved in a trading in Tibet the past with limited scope. In this regards Bishop states that Sherpas elsewhere are well known as traders between Tibet and Nepal and India, but such activity has been limited in Yolmo. However, they have a long history of circular migration in the eastern states of India (Bishop 1998: 71). This process is still continued in the Yolmo region.

\section{Agriculture}

The Yolmos practice agriculture as a means of livelihood. The main crops of potato, maize, barely, wheat and bean are intercropped on dry land. The agriculture lands are fenced with stone walls to protect the crops from animals. Barley and potatoes are the oldest crops for Yolmo in Sermathang. Later they introduced wheat and maize. After the introduction of the tourism they started to give importance to vegetable crops due to cash value at local level. Now they give growing priority to potato, turnip, radish, bean and other green vegetable because these things are in high demand in local hotels and low land people also visit Yolmo village to buy these things.

Some of them have paddy field along the banks of Melamchi and Indrawati rivers. They have rented these to Bahuns, Chhetries,
Blacksmiths and Sanyasis. Yolmo generally are not involved in paddy production because of their traditional involvement in trading and animal husbandry. Another reason is that paddy fields are located in the lowlands which are very hot and far from Yolmo villages. The low land people would like to sell their paddy fields to Yolmos because after selling the land they can continue to cultivate it as tenant. A Yolmo respondent stated that he does not visit his paddy field. The tenant sends his portion of paddy at home after harvesting the paddy.

Maize, barley and wheat are used for domestic consumption and potato is produced for both own consumption and market. However, agriculture is only a source of supplementary food because the production from land does not support the food demand of Yolmo.

They dig the land with a hoe instead of a plough. Very few of them keep oxen for ploughing. They use both family and hired laour in agriculture. There is no gender based activities in agriculture in Yolmo community. Both male and female are involved in all types of agricultural works. In Sermathang, most of the adult population migrated to Kathmandu, India and abroad for wage labour and business. The system of labour exchange has gradually decreased due to the absence of adult population in the village. The unmarried children with their parents and grand parents run their business, hotel and agriculture. Therefore the demand for agriculture labour is fulfilled by Tamang. The Tamang acquire labour opportunities in the Yolmo households at the planting and harvesting of Potato and maize. A Tamang worker told me he would prefer to work at Yolmo houses than for caste groups because he gets better food and liquor in Yolmo households. 


\section{Potato seed trade}

The local economy of Yolmo was somewhat commercialized from the beginning. Although they produce food largely for their own consumption and they sell part of the surplus. Still they practice potato-grain barter with low land people. The potato fromYolmo region is in high demanded in lowlands for planting there. It is harvested in the mouth of July-August at a time when there is a scarcity of potato in the lowlands. The lowland people usually exchange potato with their crops, mostly with wheat. The exchange value of the potato with crops is the same in the beginning of harvest. In late August and early September the price of potato increases and it has double value of wheat. One should pay 2 pathi wheat (Approximately 7 kilos) to get one pathi (approximately 3.5 kilos) potato. A large quantity of potatoes is also produced in the lowlands during the months of January to March. However, potato grown in the lowlands could not be used as seed; therefore they depend on Yolmo production. As stated by the informants, prior to 1990 the Yolmo of Sermathang visited to lowlands to exchange potato. But now the lowland people come up to the Yolmo villages with loads of wheat to exchange with the potato. This is because the Yolmo of Sermathang used to depend on potato but later they diversified their economy and they earn money from trade and foreign jobs. Thus, it appears to be a suppliers market and buyers come to suppliers rather than the reverse situation of dependency on buyers to exchange potatoes for wheat as was the case prior to 1990.

\section{Decline of herding}

Bishop (1998) mentioned that there were several gode or herding huts in Yolmo region in the early 1970s. However, at the time of my field study there were only seven families throughout the whole Yolmo region living on herding. No one was involved in the traditional zomo herding in Sermathang. An informant (an old age Yolmo) reported that there are few households in Kangyul, Tarke Ghyang and Melamchi Ghyang involving in zomo herding. There are many reasons for the reduction of zomo herding as an occupation. One of the main reasons was restrictions on herding at in the Langtang National Park in 1976 and the shift to livestock production. The second factor was the attraction of younger generation for job aboard and trade. The last one included the migration of village population to Kathmandu for work in carpet weaving.

Similarly, the traditional subsistence pattern has threatened by the park as well as by the changing priorities of the residents themselves (Bishop 1998: 163). The population of the herders has decreased due to intervention of National Park in Nepal. The observation made by Stevens (1996) in Solukhumbu also suggests that an intervention in the form of designating that a National Park discourage families from investing on livestock herds. He further adds: "A change in the policies of trekking companies and expeditions that favored the use of porters rather than pack stock would certainly also dramatically effect regional stock numbers and fodder requirement" (1996). Now job at a hotel at confer considerable status to Yolmo rather than zomo herding. Zomo herding becomes least preferable for them. Some of the households keep water buffaloes, cows, goats and sheep in small number. All of them are stall fed.

\section{Tourism, Hotel and Lodge Business}

Hotel and lodge business in Yolmo region is recent a phenomenon started in 1980. The growth of hotel and tourism in the last twenty four years has expanded the Yolmo niche further. The expansion of the hotel and tourism has been the result of the opening of new tourist destination for Halambu by Government. This concept was 
brought by the Langtang National Park. The park provided training to Yolmo in hotel management for the tourist promotion in the region. Sermathang is on the main trekking route to and from Langtang National Park. According to the LNP records more than 5,000 tourist visit each season. There are twenty-five hotels and lodges in Sermathang handled by Yolmo. Langtang Ecotourism Project (1996-1999) has launched and implemented a community based tourism activity with the co-operation of Langtang National Park (LNP 2001). LNP provided trainings for cooking and lodge management. The park also introduced solar system. Hotels and lodges are good sources of income of the Yolmo but this business is only seasonal. Hotels are mainly managed by the female members, elderly people and unmarried siblings. The facilities in Yolmo hotels are reasonably well. Tourism helps them to establish good relation with western people especially with American and European. This relation often makes it possible to enter into marriage ties between Yolmo and western people. This network helps them to expand their seasonal migration to western countries, too. The Yolmo involvement in trekking (as tourist guide and porter) is low in comparison to the Sherpas in other parts of the country. However, the number of Yolmo involved in the hotel and lodge business is encouraging.

Though tourist number is increasing, competition among the hotels is increased. Many hotels are offering free tea or reduced lodging (or even free lodge) rate in turn they may charging higher rate in food items. Such competition is high in off-season. In the time of peak season of trekking they have mutual competition among them. They do not want to accommodate whatever numbers of tourists come to their hotels. They keep reasonable number of tourist so that they can extend service properly. The exclusionary competition among the hotel owners was not noticed during the field visit.

\section{Seasonal Labour Migration}

The seasonal migration is a major survival mechanism of Yolmo. Seasonal and circular migration is an old-age tradition for Yolmo. It started in Yolmo region in the early 1950s. "Earlier migration was in permanent nature. However, in the 1970s and 1980s circular migration over short- and long-term cycles become increasingly common" (Bishop 1998:74). The past studies (Clark 1980; Bishop 1998) show that number of Yolmo used to migrate in North Hill States (Nagaland, Assam and Arunachal Pradesh) of India seasonally. Now the destination of migration is diverse and now they are working in western countries and northen state of India (Himanchal Pradesh, Kasmir, etc) also. As stated by informants, they work in different field such as road construction, carpentry and as porters. As stated by Bishop the female migrants with young children worked providing food, tea, home-distilled liquor, and ran tea shops or hotels where workers sleep, socialize, and gamble( Bishop 1998:71). During my field visit I met three seasonal migrants and they confided that they prefer to go India instead of working in their own village. They argued that the daily wages in India was higher. Similarly, the job in India was available throughout the year which is not the case at house. There is no fixed time for departure for seasonal migration but generally they move from the month of March and come back to village before Lhosar. In some cases the period of migration is longer and they come back after two years. Sometimes the duration of migration is determined by the type of family. If the migrant is from joint family he migrates with spouse including their unmarried children. In such a case the duration of migration is longer than single person migration.

Migration an abroad is recent phenomena in Yolmo region. Migration to western countries started along with the tourism development in Yolmo region. The duration of migration to western 
countries is longer than migration to India. There are seven cases of out migration to western countries in Sermathang and some of these are due to marriages.

\section{Conclusion}

The above discussion shows that there have been a number of changes in Yolmo region. In order to adapt in this mountain environment they profess multiple economic activities simultaneously. The agricultural intensification in the Yolmo land is very low. Herding is limited due to intervention of National Park and declining interest of younger generation. Similarly the population growth also compelled the Yolmo to seek job outside from the zomo herding. They efficiently exploit multiple areas (local, regional and international) for their survival. They have found out new niches and expanded old one in course of their adaptation. The cultural adaptation of Yolmo is not just confined in immediate local environment but is diversified into multiple levels and areas. Many new things come in place in Yolmo region such as tourism, hotel, Forest User Groups, etc. The technological aspects of Yolmo have changed tremendously. For example they have almost given up zomo herding and have entered into new area such as hotel business. However, the effect of technological change on organizational and ideological behaviour is very limited. They also accommodate the Buffer Zone idea into their culture. Now they form Forest User Groups to manage the local forest. They are fully aware of environmental conservation, management and utilization. They realize that if the forest of Yolmo region degrades the numbers of tourist visitors could decline because many of them come in this region to observe the bio-diversity of the National Park. Due to tourism they became successful in expanding their circular migration up to Europe and America which was mostly confined to North-eastern states of India before 1980s. There is a drastic change in transhumant herding. Some changes are also to be noticed in the field of agriculture and animal husbandry. They started to keep few numbers of water buffaloes and cows in a stall fed manner instead of zomo. They started to give little emphasis to agriculture and put more focus on wage labour and business. Likewise, some noticeable changes have taken place in the social institution of Yolmo community. For example, they started cross cultural marriage due to modern education and influences of Hindu culture. There are some instances of cross-cultural marriage between Yolmo and Europeans/ Americans. Similarly, because of contact with other cultures in Nepal and exposure to new ideas and materials, many Yolmos no longer wear their traditional dress.

Although several changes have occurred in the Yolmo region many of the traditional beliefs and cultural values remain unchanged. They have maintained cultural and social value system while adapting to the new economic strategies. The role of Lama for Yolmo is still significant and functional. The Yolmo, wherever they live, they contribute for ghang in their turn.

There are several ghyang (monasteries) and mane throughout the region. The Yolmo maintain all of the ghyangs themselves. Besides, the regular worshipping and prayers, Tibetan Buddhist and Yolmo language are also taught at the ghyang. Training in thanka painting and crafts is organized for Yolmo youth at the ghyang. They have good source of cash income from hotel and wage labour but still they have continued their agricultural economy. They are continuing the rituals relating to transhumance although they have almost given-up zomo herding.

\section{Note}

1. This article is based on a field study undertaken during July/ August 2003 in Melamchi valley with the support of Melamchi Water Supply Project. In course of my fieldwork, I collected data for Yolmo 
adaptation and some of the data I have borrowed from our joint report (Ethnic Minority Development Plan) produced by Stephen Sparkes and myself for Melamchi Water Supply Project. However, I am fully responsible for ideas and views presented in this article.

2. gode $=$ refers both to the temporary shelter constructed from bamboo mat over a framework of poles in which herding families live and to living as a herder.

3. Angsa $=$ portion of property inheritated from parents.

\section{References}

Bennett, John W., 1976. The ecological Transition: Cultural Anthropology and Human Adaptation, New Yark: Pergamon Press Inc.

Bennett, John W., 1996. Human Ecology as Human Behaviour Essays in Environmental and Development Anthropology, USA: Transaction Publishers.

Bishop, Naomi H., 1998. Himalayan Herders: Case Studies in Cultural Anthropology series (eds) George and Louise Spindler, New York: Harcourt Brace College Publishers,

Boulding, Kenneth E., 1978. Ecodynamics: A New Theory of Societal Evolution, London: Sage publications, Beverly Hills.

Central Bureau of Statistics, 2002. Population of Nepal, Central Development Region, Kathmandu: HMG/N National Planning Commission Secretariat CBS, in Collaboration with UNFPA, Nepal.

Chetri, Ram Bahadur, 1987. Migration, Adaptation and Socio-Cultural Change: The Case of the Thakali in Pokhara pp 43-69, In James F. Fisher (ed) Occasional Paters in Sociology and Anthropology vol I Kathmandu: Central Department of Sociology and Anthropology.

Chetri, Ram Bahadur, 1990. Adaptation of Tibetan Refugees in Pokhara, Nepal: A study on Persistence and change. Unpublished PhD Dissertation in Anthropology, University of Hawaii, Honolulu.

Clark, Graham E. 1980. "A Helambu History" Journal of the Nepal Research Centre (Humanities) 4:1-38.
Desjarlais, Robert, 2003. Sensory Biographies: Lives and Death among Nepal's Yolmo Buddhists, USA: University of California Press.

Fricke, Thomas E., 1993.Himalayan Households: Tamang Demography and Demographic Processes, Delhi: Book Faith India.

Graner, Elvira, 1997. The political Ecology of Community Forestry in Nepal, Germany: Printshop, Frensdorf.

Hardesty, Donald, 1977. Ecological Anthropology. New York: John Wiley and Sons.

HMG/UNDP, 1998.Park People Programme, Annual Project Report, Kathmandu: Department of National Park and Wild Life Conservation/ Park People Programme.

Howell, Signe, 2003. The house as analytic Concept: A Theoretical Review pp 16-33 in Stephen Sparkes and Signe Howell (eds) The House in Southeast Asia: A changing Social, Economic and Political Domain, London: Rout ledge Curzon.

LNP, 2001. Buffer Zone Management Plan of Langtang National Park: Rasuwa, Langtang National Park.

Metz, J.J., 1989. Himalayan Political Economy. More Myths in the closest? PP 9 (2): 175-186 In Mountain Research and Development.

Molnar, Augusta, 1981. "Economic Strategies and Ecological Constraints: Case of the Kham Magar of North West of Nepal" pp 20-51 In C. Von Furer Haimendorf (ed) Asian High Land Societies: In Anthropological Perspective, New Delhi: Sterling Publishers Pvt. Ltd.

Sparkes, Stephen and Binod Pokharel, 2003. Ethnic Minority Development Plan, Social Uplift Programme (SUP)- Melamchi Diversion Scheme an Unpublished Project Report, Kathmandu.

Stevens, Stanley F., 1993. Claiming the High Ground. Delhi: Motilal Banarsidass Publishers Private Limited.

Steward, Julian.1955."The Concept and Method of Cultural Ecology" pp, 30-42 (Chapter 2). TheTheory of Culture Change. Urbana: University of Illinois Press. 